locality being in Kent. It is therefore of the highest importance that one should know for certain whence the gravel has been derived that one sees on the roads.

I live in an implementiferous district, and find Palrolithic implements in the Highbury and Clapton gravels; but a visitor would make a fatal mistake if he supposed that all the gravel on the roads about here belongs to the district. Sometimes many tons of gravel are brought here from Walthamstow; at other times from Ware or Hertford; sometimes from Dartford, and from other places. Unless, therefore, the greatest possible care is taken in ascertaining the exact locality whence the ballast comes, mistakes are certain to occur.

The lowest gravels about here are unproductive of the works of primæval man, with the exception of, at times, a stray flake or two, probably derived from a higher level. The evidence that I have seen in the lower gravels round London points to the correctness of the conjecture made by General Pitt-Rivers, that the Palæolithic age had passed away before the lower parts of the Thames Valley were excavated.

125, Grosvenor Road, Highbury, N.

$$
\text { WORTHINGTON G. SMITH }
$$

\section{How to Prevent Drowning}

I HAVE read with some interest Dr. MacCormac's letters on the subject of water-treading as means of preventing drowning.

I am sorry that I cannot agree with him, as it would be decidedly a matter of congratulation if some practical means of diminishing the number of casualties from drowning were found. Personal experience, however, prevents my agreeing with $\mathrm{Dr}$. MacCormac.

I am a tolerably good swimmer, can swim in all the different fashions, but I can neither float nor tread water.

Shortly after Dr. MacCormac's first letter appeared I went to swimming baths with a view of putting the matter to the test. I had carefully read Dr. MacCormac's letter, and determined to give it a fair trial. I minutely observed all his directions, and invariably sank every time I tried his plan.

Now it must be remembered that I am a swimmer, and so far as swimming goes, perfectly at home in the water. Moreover, I was not in the least flustered. When I sank I made no attempt to rise again by swimming; I remained in what Dr. MacCormac would call the orthodox position for treading water, only opening my eyes in order to see whether I was ascending or descending. As however I found that I continued to do the latter until I reached the bottom of the bath, and there seemed to be no probability that I should rise without some further effort, I was at last compelled to make this effort.

This was the course of affairs every time I made the attempt. Moreover, whenever I essayed to float on the surface, although I carefully assumed the correct position, threw my head wel back, and took the deep inspiration, the result was the same.

Arguing from these facts, it seems to me pretty clear that it is not everybody who can tread water or float. Why this is so, appears to me to lie in the fact that the human body is not always lighter, bulk for bulk, than water. Perhaps with plump children and others with plenty of adipose tissue about their frame this may be the case, but with spare people who consist mainly of muscle and bone, the specific gravity must be greater than that of water: The body of a fish when the animal is dead will sink until decomposition sets in and causes it to float.

For these reasons I fear that Dr. MacCormac's suggestion will not be found of so much practical use as he hopes. The apparent ease of the process described by Dr. MacCormac may in itself be the cause of rash proceedings by those who cannot swim, and may so lead to greater loss of life, the very evil which the suggestion is intended to diminish.

\section{I, Holloway Road, N., June 7}

\section{W. Henry Kesteven}

ON the Continent the facilities are greater than in England, where factories and steam-boats spoil the pleasure of swimming, and everybody is well aware that all can foat upon fresh water without assistance from their hands and feet. It is what in the Paris swimming-schools is called "faire le mort."

Anybody-stout, lean, cripple, halt-is able to do so, and I taught, myself, a poor little hunchback how to perform this easy feat; but his deformity placing him in a state of unstable equilibrium, he was obliged to keep his arms stretched at an angle from $45^{\circ}$ to $60^{\circ}$.
Some minutes are sufficient in fresh water to make a proficient and a live "mort." The way to do it is very simple, and $\mathrm{Mr}$. MacCormac described it very exactly, with the omission of some particulars relating to the way of breathing, which had no direct reference to his chief and beneficial topic, "treading water."

He who wishes to "faire le mort" must first draw a deep breath, and keep it, then put himself on his back, with his head thrown backwards, as recommended by Mr. MacCormac, and allow his limbs to droop slackly without any stiffness, no matter in what position.

The body will sink at first under water, but it will immediately rise nearly on a level with the surface, the only parts quite free from water being the chest and the nose and mouth, around which the water describes an oval, whilst the eyes are at times over, at times under, water.

The "mort" can remain floating in this way as long as his breath allows, though it is better not to wait longer than two or three seconds, to avoid fatigue ; then he must quickly emit it, draw another deep breath, and keep it again.

The body sinks as before, rises immediately, regaining its floating position, nose, mouth, and chest emerging again from water.

This can be continued for hours together without the least motion of legs or arms, as your readers will be able to verify for themselves, either at the Pont Royal or Ligny swimming schools, on their visit to the Paris Exhibition of Electricity.

Jersey, June 5

Chatel

P.S.-I ought to add that whilst floating on fresh water the body is not quite on a level with the surface, but from the chest, that is out of water, to the toes, which are about six or eight inches under water, figures an inclined plane, the slope of which varies with everybody, and that any attempt to bring the toes on a level with the surface makes the body sink. On the contrary, the deeper the head is sunk backwards under water the more the body emerges.

\section{Auroric Light}

JUNE 6, faint lights, especially to the northward, between ro and 12 ; smart frost.

June 7 , at 10, masses of purplish light rising from the northeast and congregating about the zenith; pencils of greenish yellow and white rising to the north ; these continued up to I2, after which no observations were made; very smart frost, which bit the potato stalks.

June 7 , from 1o to 12, well-marked and at times brilliant columns, pencils, and masses of red rising all round the heavens at intervals, and congregating at the zenith; a most severe white frost that burnt up all the potatoes on the valley flats and on the uplands. At 5.30 on the 8 th the frost was so thick that the ground had the appearance as if it had snowed during the night. Ovoca, Ireland, June IO

G. H. KinahaN

\section{A Singular Cause of Shipwreck}

In NATURE, vol. xxiv. p. 106, you mention a "singular case of shipwreck" caused by waves and spray freezing on a steamer and sinking it by its weight. Cases of this kind caused by frozen spray alone are known near the east coast of the Black Sea. North of $44^{\circ}$, where the mountains are not very high, an exceedingly strong and sudden north-east wind is frequent, quite similar to the Dalmatian Bora, and called alike. It descends at a certain angle to the sea, raising a great quantity of spray. In winter this spray immediately freezes, and ships may sink by its weight. On January 25,1848 , a war-ship, anchored in the middle of the Bay of Noerrossiisk, sank in this manner. As the weather was fine before, a great part of the crew were ashore, and the storm arrived with such suddenness that the ship sank from the weight of the frozen spray. On account of the bora this coast is avoided by merchant-ships in winter, and visited only by a line of steamers subventioned by the Government.

$$
\text { St. Petersburg, June } 8
$$$$
\text { A. WOEIKOF }
$$

OBSERVATIONS ON THE HABITS OF ANTS

N Thursday (June 2) Sir John Lubbock read a further paper on this subject at the meeting of the Linnean Society. He said that in one of his former papers 